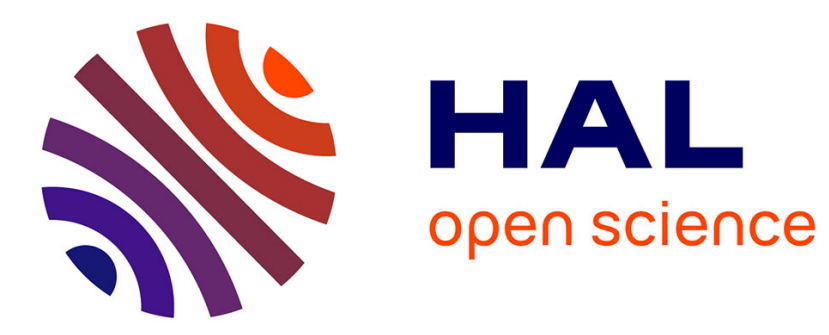

\title{
Pay Gap Between Male And Female Physicians
}

William B. Weeks, Bruno Ventelou

\section{To cite this version:}

William B. Weeks, Bruno Ventelou. Pay Gap Between Male And Female Physicians. Health Affairs, 2020, 39 (5), pp.906. 10.1377/hlthaff.2020.00091 . hal-02734593

\section{HAL Id: hal-02734593 https://hal-amu.archives-ouvertes.fr/hal-02734593}

Submitted on 12 Feb 2021

HAL is a multi-disciplinary open access archive for the deposit and dissemination of scientific research documents, whether they are published or not. The documents may come from teaching and research institutions in France or abroad, or from public or private research centers.
L'archive ouverte pluridisciplinaire HAL, est destinée au dépôt et à la diffusion de documents scientifiques de niveau recherche, publiés ou non, émanant des établissements d'enseignement et de recherche français ou étrangers, des laboratoires publics ou privés. 


\section{Pay Gap Between Male And} Female Physicians

Using New York State survey data for 1999-2017, Anthony Lo Sasso and coauthors (Feb 2020) found sex-based disparities in physicians' starting pay, even after they adjusted for important variables. We have two comments on the research.First, when there are substantial differences in the sample's high-paying specialty distribution between the sexes, cross-specialty comparisons may conflate specialty choice with sex-based disparities within a specialty.

Second, like every study of sex-based income differences, the authors found that male physicians work substantially more hours than female physicians do. We have proposed that overtime pay premiums might explain sex-based income differences. ${ }^{1}$ Overtime pay reimburses the sacrifice of nonfungible leisure time, and overtime pay is law: US federal law requires that wage earners who work more than forty hours per week be paid an overtime premium of at least 50 percent. $^{2}$

In a sample of about 8,500 primary care general internists, family practitioners, and pediatricians, our specialtyspecific analysis found that when hypo- thetical overtime premiums of $0-61$ percent (depending on the specialty) were applied to more than two thousand annual hours of work, significant sex-based income disparities were eliminated. ${ }^{1}$

If such reasonable levels of overtime pay premiums can explain sex-based income disparities within physician specialties, then future sex-based income disparity research might pursue a family-as opposed to a labor-economics approach to understand and address the barriers that women face in pursuing careers in highly paid specialties or having the opportunity to work more hours within their chosen specialty, if they wish to do so.

William B. Weeks

Microsoft Healthcare NExT

REDMOND, WASHINGTON

Bruno Ventelou Aix-Marseille University MARSEILLE, FRANCE

\section{NOTES}

1 Weeks WB, Ventelou B. Exploration of leisure time valuation to explain sex-based wage gaps among salaried primary care physicians in the US. Journal of Reviews on Global Economics. 2017;6:395-403.

2 Department of Labor. Overtime pay [Internet]. Washington (DC): The Department; [cited2020 Jan 27]. Available from: https://www.dol.gov/ agencies/whd/overtime 